\title{
Daily rhythms count for female fertility
}

Valérie Simonneaux $^{1 *}$, Thibault Bahougne ${ }^{1,2}$ and Eleni Angelopoulou ${ }^{1,3}$

${ }^{1}$ Institut des Neurosciences Cellulaires et Intégratives, UPR CNRS 3212, 5 rue Blaise Pascal 67084 Strasbourg, France ;

${ }^{2}$ Service d'Endocrinologie et Diabète, Hôpital Civil, Hôpitaux Universitaires de Strasbourg, Strasbourg, France

${ }^{3}$ Department of Endocrinology and Metabolism, Academic Medical Center (AMC), University of Amsterdam, Amsterdam, Netherlands

Valerie Simonneaux, PhD and director of research; simonneaux @inci-cnrs.unistra.fr; tel: $33+388456671$; fax: $33+388456654$

Eleni Angelopoulou, PhD student, angelopoulou@inci-cnrs.unistra.fr; +30 6989789506 Thibault Bahougne, MD, PhD student, tbahougne@ gmail.com; phone : 33+3 88116607

*Corresponding author

Number of words: 5071 (without references \& figures)

Number of figures: 2 


\section{Practice points}

- Ovulation is triggered by a marked and transitory LH surge occurring at a stage when oocytes are mature and at the end of the daily resting period.

- The LH surge is gated by high circulating estradiol produced by the ovaries and a circadian signal driven by the hypothalamic master biological clock.

- The circadian signal is forwarded by the hypothalamic master clock towards two distinct neuronal populations. The kisspeptin expressing neurons which stimulate and the (Arg)(Phe)related peptide (RFRP) expressing neurons which inhibit the GnRH-driven LH secretion.

\section{Research agenda}

- The circadian regulation of the pre-ovulatory LH surge needs to be investigated in diurnal rodents and non-rodent species

- The effect of circadian disruption (jet-lag or shift work) on reproductive capacity needs to be experimentally investigated

- Rigorous epidemiologic studies should be performed to assess the effect of shift work on fertility of women. 


\begin{abstract}
Female ovulation depends on a surge in circulating luteinizing hormone (LH) which occurs at the end of the resting period and requests high circulating estradiol. This fine tuning involves both an estradiol feedback as an indicator of oocyte maturation, and the master circadian clock of the suprachiasmatic nuclei as an indicator of the time of the day. This review describes the mechanisms through which daily time cues are conveyed to reproductive hypothalamic neurons to time the pre-ovulatory surge. In female rodents, neurotransmitters released by the suprachiasmatic nuclei activate the stimulatory kisspeptin neurons and reduce the inhibitory RFRP neurons precisely at the end of the afternoon of proestrus to allow a full surge in LH secretion. From these findings, the impact of circadian disruptions (during shift or night work) on female reproductive performance and fertility should now being investigated in both animal models and humans.
\end{abstract}

Key words: female reproduction, pre-ovulatory LH surge, circadian clock, kisspeptin, RFRP, estradiol, shiftwork. 


\section{1- A dedicated hypothalamic network controls reproductive activity}

Gonadal activity depends primarily on a set of neurons located in the hypothalamus and producing the gonatotropin releasing hormone $(\mathrm{GnRH})$. These neurons are scattered in the preoptic area and the vascular organ of the lamina terminalis, but they mostly project at the median eminence where they release GnRH into the portal blood to further activate the synthesis and release of two gonaotropins, luteinizing (LH) and folliculo-stimulating (FSH) hormones, from the pituitary gonadotrophs. In females, FSH promotes follicular growth and sex steroid production while LH triggers ovulation of the mature follicules when the circulating level of estradiol is high enough to attest follicle maturation.

Various (neuro)transmitters have been proposed to regulate GnRH neuronal activity, but in 2003, the finding that mutations in the gene encoding the receptor of kisspeptin (Kiss1R, formerly GPR54) induces idiopathic hypogonadotropic hypogonadism in humans and mice [1][2] shed light on the pivotal role of kisspeptin on the regulation of GnRH neurons. The $\underline{\text { Kiss } 1}$ gene encodes a family of peptides generated from an initial 145 amino acid kisspeptin (Kp) propeptide, Kp145, which is cleaved into peptides of different sizes from Kp54 (previously named metastin) to Kp10. The discovery of Kp and its major role in reproductive function have been a milestone in the field of reproductive biology. An increasing number of studies now indicate that Kps are critical regulators of sexual differentiation and maturation as well as of normal adult reproductive functioning across mammalian species, including humans [3]. Kp neurons are localized within two hypothalamic areas, in the arcuate nucleus (ARN) and the rostral periventricular nucleus of the third ventricle, also called anteroventral 
periventricular nucleus (AVPV), or the preoptic area (depending on species). They send projections mainly to the GnRH neuron cell bodies (AVPV Kp neurons) and nerve terminals (ARN Kp neurons) [4][5][6]. Importantly, AVPV presents a marked sexual dimorphism with much more Kp neurons in females and it plays a specific role in driving the pre-ovulatory GnRH/LH surge [4][7][8]. Kiss1R is highly expressed in GnRH neurons but also in other brain areas and in endocrine tissues like the pituitary gland, ovary, and placenta [9][10][11]. Kp has a very potent stimulatory action on $\mathrm{GnRH}$ release and therefore gonadotropin secretion in all mammalian species investigated so far [12][13][14][15]. Central injection of doses as low as 0.1 to 1 pmole Kp10 is sufficient to evoke robust $\mathrm{LH}$ secretion in rodents and primates [13][15]. The essential role of the Kiss1/Kiss1R complex in the central regulation of the gonadotropic axis is attested by the profound impaired reproduction (abnormal sexual maturation, small uterus, ovaries without mature follicles, no estrous cycle) associated to mutations in Kiss1 [16][17] or Kiss1R [1][18][19] in mammals, including humans.

Other neurotransmitters and hormones have been reported to regulate GnRH neuron activity, albeit not to the same extent as Kp, such as glutamate which stimulates Gnrh gene expression and GnRH release during the LH surge [20][21] and nitric oxide (NO) which has been reported to coordinate GnRH neuronal activity [22]. Notably, recent studies indicate that another neuropeptide belonging to the same RF-amide peptide family as Kp, RFRP-3 (the mammalian homolog of avian gonadotropin inhibitory hormone $(\mathrm{GnIH}))$, acts at several central sites to regulate reproductive activity. RFRP-3 is encoded by the $\underline{\text { Rfrp }}$ gene (also encoding RFRP-1 with moderate if any effect on the reproductive axis) expressed in neurons exclusively located in the dorsomedial hypothalamus [23]. RFRP neurons project to various brain areas including the preoptic area and within the vascular organ of the lamina terminalis 
(OVLT) where RFRP fibers make contact with GnRH neurons and the AVPV/medial preoptic nucleus where RFRP fibers make contact with Kp neurons [23][24][25]. The main RFRP-3 binding site is reported to be the receptor GPR147 (also known as NPFF1R), but it is possible that other receptors are activated by RFRP-3 due to cross reactivity to other RF-amides receptors [26]. GPR147 is expressed in various brain areas notably those related to the central control of reproduction. Thus a significant number of GnRH neurons (15-33\%) and Kp neurons (5-25\%) express GPR147 [24][27]. Further, electrophysiological investigation on mouse hypothalamic sections has demonstrated a direct effect of RFRP-3 on GnRH neuronal firing rate with either inhibitory (41\%) or stimulatory (12\%) action [28]. Unlike Kp, RFRP-3 is mostly reported to inhibit reproductive activity [23][29][30]. However, recent studies have revealed a sex-dependant effect of the peptide. Thus in Syrian hamsters and mice, a central injection of RFRP-3 increases GnRH neuronal activity and LH secretion in males, whereas in females it reduces the amplitude of the LH surge [23][31][32]. Moreover, RFRP-3 appears to have an additional direct hypophysiotropic effect in ewes [29], although this is still disputable in rodents.

\section{The critical role of the sex steroid feedback}

Sex steroids produced by the gonads have long been known to feedback on the hypothalamopituitary axis in order to exert a retrocontrol of reproductive activity. In males, testosterone exerts a sustained negative feedback whereas in female mammals, the feedback is more complex as estradiol exerts positive or negative feedback according to the stage of the ovarian cycle and the concentration of circulating estradiol. 
During the first part of the female reproductive cycle, the low level of circulating estradiol induces a negative feedback, whereas upon oocyte maturation (at the end of the follicular phase in humans or pro-estrus in rodents), higher estradiol concentration exerts a positive feedback, causing a synchronized activation of GnRH neurons leading to GnRH release in the hypophyseal portal blood and finally the pre-ovulatory LH surge [33]. The effect of estradiol is mediated via two types of nuclear estrogen receptors (ER) which induce long lasting genomic action, $\mathrm{ER} \alpha$ and $\mathrm{ER} \beta$ [34][35], but it can also have a rapid action via the membrane bound estradiol receptor GPR30 [36][37].

Although GnRH neurons express ER $\beta$, they do not appear to be the direct site of the estradiol feedback. Indeed, mice bearing a GnRH neuron-selective deletion of ER $\beta$ exhibit normal cycles and negative feedback [38], leaving the putative role for ER $\beta$ in GnRH neuron activity still an open question [34].

In contrast to $\mathrm{GnRH}, \mathrm{Kp}$ neurons have a high density of ER $\alpha$ and are therefore considered as the pivotal node for the estradiol feedback [7][39][40]. Interestingly, in rodents the estradiol feedback depends on Kp neuron localization as estradiol stimulates Kiss1 expression in the AVPV while it inhibits Kiss1 expression in the ARN [40][41][42][43]. In non-rodent mammals, a similar differential regulation by estradiol is also observed with a stimulatory effect in the rostral periventricular/preoptic area and an inhibitory effect in the ARN [44][45]. It has been proposed that AVPV $\underline{\text { Kiss1 }}$ activation requires an estrogen response element (ERE)-dependent pathway, whereas inhibition of Kiss1 expression in the ARN involves EREindependent mechanisms [41][46]. Notably, mice lacking ER $\alpha$ specifically in Kp neurons 
display an advanced puberty and extremely irregular estrous cycles, further demonstrating the role of Kp neurons in conveying the estradiol feedback towards the GnRH neurons [47].

The effect of estradiol on RFRP neurons remains questionable according to studies. Indeed a portion of RFRP neurons has been shown to co-express ER $\alpha$ in female rodents [23][48]. In some studies estradiol has been shown to induce c-Fos expression in RFRP neurons [23] and to stimulate Rfrp expression [49]. In contrast other studies have reported that estradiol decreases Rfrp expression [48][50] or has no effect [32][51]. Thus, additional studies are required to clarify whether estradiol regulates RFRP neurons and, if so, to assess putative sex differences in its effect.

\section{3- The hypothalamo-pituitary-gonadal axis displays rhythms}

In adulthood, the reproductive axis is highly rhythmic with different periodic time scales going from a few minutes (GnRH pulsatile release) to days (LH surge in female), weeks (ovarian cycles in female) or months (seasonal reproduction).

$\mathrm{GnRH}$ secretion is pulsatile and this is critical to induce proper gonadotropin secretion as there is a tight correlation between GnRH and LH pulsatilities [52]. Thus, discontinuous but not constant administration of exogenous $\mathrm{GnRH}$ is capable of restoring reproductive activity in patients suffering from Kallmann syndrome [53]. Increasing evidence suggests that ARN Kp neurons which co-express neurokinin and dynorphin (KNDy neurons) drive GnRH 
pulsatility [54][55]. Notably, Kp release in the stalk-median eminence is pulsatile [56], and pulsatile Kp drives LH secretion in juvenile monkeys [57]. A recent study reported that pulsatile administration of Kp was able to evoke a dramatic synchronous activation of $\underline{\mathrm{GnRH}}$ gene transcription with robust stimulation of $\mathrm{GnRH}$ secretion in murine cultured hypothalamic explants [58].

In female mammals, ovarian activity displays regular cycles (menstrual cycles in women, estrous cycles in rodents) driven mostly by the change in circulating pituitary gonadotropins. During the first part of the reproductive cycle (follicular phase in women; metestrus-diestrus in rodents), FSH secretion increases, leading to the recruitment and development of ovarian follicles. The growing follicules cause a progressive increase in estradiol associated with a higher LH receptor expression in granulosa cells [59]. During this early phase, LH pulses occur with a high frequency and stable low amplitude. The second part of the reproductive cycle (luteal phase in women; proestrus-estrous in rodents) begins with a marked and transient secretion of LH. This LH surge induces the ovulation of mature follicles, the continuation of oocyte meiosis, and an arrest of granulosa cell proliferation. Ovulation generally occurs a few hours after the LH surge in rodents, and 24-48 hours after the LH surge in women. The length of the ovarian cycle is approximately 4-5 days in rodents and 28 days in women. The occurrence of the LH surge not only requires high circulating estradiol as an indication of follicle maturation but also a daily signal. Indeed the LH surge arises at a very specific time of day, usually at the end of the resting period, thus in the late afternoon in nocturnal rodents [60][61][62] and the end of the night/early morning in the diurnal rodent Arvicanthis [63] and in humans [64]. Such timing requires that the GnRH neurons receive a correct daily signal and the mechanisms by which this is achieved are discussed below. 
Most species show additional seasonal cycles in reproductive activity. Indeed, except for the inbred laboratory mice and rats and species like humans living all year long in rather stable conditions, animals living in the wild adapt their breeding activity to the seasonal change in their environment. Early studies have demonstrated the pivotal role of the pineal hormone melatonin in this process [65][66]. Melatonin is a reliable endocrine representation of the seasons since its production at night is proportional to night length. Changes in circulating melatonin by pineal lesion or timed melatonin infusion have profound effect on the occurrence and timing of the reproductive activity. It is now well established that melatonin acts mainly at the pars tuberalis of the pituitary to regulate thyroid stimulating hormone (TSH) synthesis. This TSH in turn acts on the tanycytes located at the basal part of the third ventricle to regulate deiodinases 2 and 3 expression, leading to increased hypothalamic levels of T3 in long day conditions [67]. In male and female seasonal rodents, the higher TSH/T3 signal in spring/autumn increases RFRP and Kp expression and further stimulates the gonadal activity [32][40][68][69][70].

\section{4- Evidence for a circadian control of the pre-ovulatory surge}

Most biological functions are synchronized to the daily variation of environmental factors using the recurring light/dark cycle. The mechanisms by which light and dark synchronize biological functions involve the retino-hypothalamic tract (RHT) which transmits the light to the hypothalamic suprachiasmatic nuclei $(\mathrm{SCN})$, locus of the master biological clock in the non-visual light system. SCN neuronal/hormonal outputs then convey the daily cues to downstream central and peripheral structures. The circadian activity of the SCN neurons relies 
on a complex molecular system cycling endogenously with a period of about one day [71][72]. This molecular clockwork is composed of transcription-translation loops involving the binding of CLOCK/BMAL1 dimers on E-box to promote transcription of other clock genes whose proteins form PER/CRY dimers which in turn repress their own transcription by competing with the CLOCK/BMAL1 binding. This results in sustained cycles with a period of about 24h (circadian) which are observed for weeks or months in isolated SCN explants or dissociated cells. The SCN circadian activity is synchronized to a period of exactly $24 \mathrm{~h}$ (diurnal) by the daily change in light intensity perceived by melanopsin-containing intrinsically photosensitive retinal ganglion cells projecting directly to the SCN via the RHT [73][74]. Upon light activation, these ganglion cell terminals release glutamate and pituitary activating cAMP peptide (PACAP) which change the phase of (synchronize) the circadian clock machinery. The CLOCK/BMAL1 dimers not only activate canonical clock gene expression, but also other clock-controlled genes whose promoters display E-boxes and therefore undergo rhythmic expression. This mechanism was first demonstrated for the gene encoding vasopressin, an important output of the SCN clock [75]. Levels of SCN vasopressin mRNA are markedly higher during the day than at night, while in Clock mutated mice the SCN vasopressin rhythm is strongly dampened [76].

Although the master SCN circadian clock is essential in driving biological rhythms, it is now established that secondary clocks located in other central structures and organs are part of a complex a multi-oscillator system [77]. The use of Per2::LUCIFERASE transgenic mice, where the Per2 promoter drives the expression of the luciferase gene, was decisive for the demonstration that non-SCN structures can sustain endogenous circadian oscillations [78]. Although the strength of these secondary clocks is often less than that of the SCN, an 
increasing number of studies report that they may play a critical role in the biology of the host structure [79]. In this context, the hypothalamo-pituitary gonadal axis also appears as a functional multi-oscillatory axis since all reproductive structures from the hypothalamic Kp and GnRH neurons down to the ovaries and the uterus display endogenous circadian oscillations of clock genes [80]. Notably, we recently reported that virtually all AVPV Kp neurons express the PER1 protein with a daily rhythm and that isolated Kp-expressing AVPV explants from PER2::LUCIFERASE mice display endogenous estradiol-sensitive circadian oscillations with a period of about $23 \mathrm{~h}$ [81]. Further, a recent study also reported that RFRP neurons express PER1 with daily variation [82]. Yet, the functional role of these reproductive clocks with regards to the timing of reproduction (ovulation, implantation, parturition) has still to be determined.

The timing of the pre-ovulatory LH surge strongly depends on a functional circadian clock. Indeed, the LH surge not only requires a critical threshold of estradiol produced by the developing ovarian follicles, but it is also gated at the end of the daily resting period. Thus, in female nocturnal rodents like mouse, rat or hamster, the surge of LH occurs at the day(rest)/night(wake) transition of the proestrus stage whereas in the few diurnal mammals investigated the LH surge occurs at the end of the nocturnal resting period. The daily signal driving the LH surge onset arises primarily from the master SCN clock since early experiments of SCN lesions [83] or cuts of the SCN-preoptic area neuronal connection [84] resulted in an impaired LH surge and estrous cyclicity in female rats. Furthermore, female mice carrying mutations of $\underline{\text { Clock }}$ or Bmal1 display disrupted estrous cycles $[85][86][87][88][89]$. In humans it was reported that women with single-nucleotide polymorphisms in the ARNTL ( $\underline{\text { Bmal1 }}$ ) have more miscarriages and less pregnancies [90]. 


\section{Neuroanatomical and pharmacological evidences of functional connections between the SCN and GnRH neurons}

SCN neurons contain various neuropeptides, notably vasopressin and vasoactive intestinal peptide (VIP), whose synthesis displays daily variation. These neurons project to various brain areas to help synchronizing biological function with the time of the day. Early studies have demonstrated that central injection of vasopressin or VIP antagonists (or antibody) reduces the amplitude of LH surge in female rodents, clearly indicating that these peptides may be involved in the daily gating of the LH surge [91][92][93][94][95].

Recent studies indicate that the SCN signal the time of day to GnRH neurons indirectly via vasopressinergic fibers projecting to the AVPV Kp neurons [96][97]. Anterograde tracing studies show that vasopressin-containing axons originating from the SCN make appositions to Kp neurons and these neurons express V1a receptors. Notably, vasopressin is released with a peak coinciding with the onset of the LH surge [98]. The vasopressin input to Kp neurons is sensitive to estradiol since estradiol treatment significantly increases the number of vasopressin terminal appositions on individual Kp neurons [97] and the rhythm in V1a mRNA is abolished in ovariectomized animals [81]. Furthermore, vasopressin activation of Kp neurons is critically dependent on circulating estradiol as vasopressin no longer activates Kp neurons in ovariectomized mice, an effect that is fully restored by estradiol treatment [99]. A recent study reported that intracerebroventricular administration of vasopressin in female 
Syrian hamsters activates Kp neurons similarly in the early or late part of the day, while in the same animals GnRH neurons are activated only late in the day [96]. Altogether, these results are consistent with the hypothesis that Kp neurons located in the rodent AVPV receive daily information from the SCN via a vasopressinergic monosynaptic pathway, a signal which is modulated (gated) by circulating estradiol. Vasopressinergic fiber projections are also found on RFRP neurons, but central administration of vasopressin does not appear to regulate RFRP neurons [82].

A significant role of the SCN-derived VIP output in female reproduction should not be excluded. Indeed, VIP neurons project onto GnRH neurons in a sexually dimorphic manner, with female rats exhibiting higher VIPergic innervation than males [100]. On the contrary, very few or no VIP terminals were found to make appositions on to Kp neurons [96][97]. Notably, recent studies reported that SCN-derived VIP neurons project to RFRP neurons and that central administration of VIP decreases RFRP neuronal activity in the afternoon, but not in the morning, of the proestrous stage [82]. Therefore, it seems likely that a SCN-derived VIPergic signal regulates RFRP activity. However, RFRP cells do not appear to express VIP receptors, suggesting that VIP regulation of RFRP neurons may be indirect [82].

Thus, rodent studies indicate that the SCN clock predominantly uses a vasopressin, estradiol dependant, signal towards AVPV Kp neurons and a VIP signal towards RFRP neurons, via a yet undetermined target, to forward daily cues to the reproductive axis (figure 1). Further, it cannot be excluded that putative secondary clocks operating within the Kp and RFRP neurons may play a role in timing their cellular activity. 


\section{Role of Kp and RFRP in relaying circadian signal to GnRH neurons}

The putative role of Kp and RFRP neurons as a relay between the SCN clock and the daily GnRH/LH surge presumes that their neuronal activity displays daily changes coordinated with the onset of the LH surge.

Actually, under high circulating estradiol condition (either in proestrus or in ovariectomized/estradiol implant conditions) Kp neuronal activity (as seen by c-FOS activation) and Kiss1 expression are significantly increased about 3 hours before lights off, thus 2 hours before the LH surge in female rodents [81][96][101][102]. On the opposite, Kp immunoreactivity is markedly but transiently decreased suggesting a release of the Kp peptide at the same time [102]. Under low circulating estradiol conditions, in diestrus or in ovariectomized animals, the daily variation in neuronal activity, Kiss1 mRNA and Kp immunoreactivity is abolished or strongly dampened [81][101][102]. These data indicate that in female rodents, Kp neurons are activated at the day/night transition (end of the resting period) only during the proestrus stage, in coordination with the LH surge (figure 1). Intracerebroventricular injection of vasopressin induces c-FOS expression in Kp neurons and increases Kiss1 mRNA [96] while vasopressin incubation of hypothalamic sections activates Kp neuron firing rate [99]. Altogether these data demonstrate that only under high circulating estradiol (when oocytes are mature enough to be released), Kp neurons can be activated by the SCN-derived vasopressin in order to increase Kp synthesis and release. Given the highly 
potent stimulatory effect of $\mathrm{Kp}$ on $\mathrm{GnRH}$ release and LH/FSH secretion, this SCN-driven activity of Kp neurons is pivotal for the daily gating of the LH surge. All these studies have been performed in nocturnal female rodents, thus similar investigations should be performed in diurnal mammals to assess whether Kp neuronal activity is increased at late night together with the LH surge.

RFRP neurons also display a daily rhythm in neuronal activity in the various female rodents investigated [32][103][104]. Unlike Kp neurons, however, the number of c-FOS expressing neurons is decreased at end of the day of the proestrus stage, thus at the time of the LH-surge (figure 1). Similarly, in ewes RFRP expression is reduced during the pre-ovulatory period [105]. In the female hamsters, this daily decrease in RFRP neuronal activity is observed not only at the proestrus, but also at the diestrous stage thus indicating that in contrast to Kp neurons, the daily regulation of RFRP neurons does not depend on circulating estradiol [32]. Given the robust inhibitory effect of RFRP-3 on the GnRH/LH pre-ovulatory surge, these findings point towards a specific daily rhythm in RFRP expression and release in females, which serves to down-regulate the inhibitory RFRP activity at the time of the LH-surge.

Altogether, it is tempting to speculate that the SCN master clock uses two different nervous pathways (vasopressin and VIP) to drive a coordinated increase of the stimulatory Kp neurons and decrease of the inhibitory RFRP neurons to allow a full stimulation of the GnRH/LH surge at the end of the resting period (figure 1). 


\section{7- What happens when the daily activity goes wrong?}

\section{Concept of shift work}

The modern $24 \mathrm{~h}$-functioning society requires an increasing number of employees to work outside of the natural active period, in shifted conditions. According to the International Labor Organization (ILO; 1990), working in shifts is "a method of organization of working time in which workers succeed one another at the workplace so that the establishment can operate longer than the hours of work of individual workers". Shift work and night work cover a multitude of realities: different time systems called $2 \times 9,3 \times 8,4 \times 8,5 \times 8,2 \times 12$ hours with variability resulting from different choices made by the employer's company.

Nowadays in industrial countries, 20-30 \% men and 15-20\% women experience shift work or work at night [106], and this is an expanding phenomenon with a particularly significant increase among women under 30 years. One difficulty to define shift/night work comes from variable definitions, even within the European Union. Thus, in France, night work is defined as any work between $9 \mathrm{pm}$ and $6 \mathrm{am}$; in Germany it is 2 hours of the daily work between 11 pm and $6 \mathrm{am}$; in Italy it is a minimum of 7 consecutive hours between $0 \mathrm{am}$ and $5 \mathrm{am}$; in Belgium it is performed between $8 \mathrm{pm}$ and $6 \mathrm{am}$; and in the United Kingdom, it is 3 hours of the daily work between $11 \mathrm{pm}$ and $6 \mathrm{am}$. Moreover, shift work can be defined by a number of periods, duration of the periods, shift structure (continuous or not), start and end time of work, and overlapping time between shifts. 


\section{Impact on health in general}

An increasing number of studies reports that shift work or night work is often associated with increased risks of developing cardiovascular/metabolic/gastro-intestinal disorders, some types of cancer, and mental disorders including depression and anxiety [107][108][109]. Hence, in 2007 shiftwork was reclassified from a possible to a probable human carcinogen (class 2A) by the International Agency for Research on Cancer.

Many epidemiological studies and meta-analyses have reported a correlation between shift/night work and risks of metabolic disorders and cardiovascular diseases such as obesity or overweight, diabetes, hypertension, dyslipidemia, or metabolic syndrome. Bøggild and Knutsson (1999), who analyzed 17 studies (between 1949 and 1998), evaluated the excess risk at $40 \%$ for ischemic heart disease in shift/night workers compared to day workers (relative risk was ranging from 0.4 to 3.6 , with a majority between 1 to 2) [110]. Ten years later, Frost et al. published a new review (from 16 epidemiological studies done between 1972 and 2008) which reported a limited epidemiological evidence for a correlation between shift/night work and ischemic heart disease [111]. More recently, a large meta-analysis (34 studies published between 1983 and 2011, including more than two million people) indicated that shift/night work is associated with a significant increase in myocardial infarction and coronary events with or without adjustment for other risk factors [112]. Since then, four other epidemiological studies have indicated an increased risk of coronary events and 
cardiovascular disease mortality after 5 years of shift/night work [113][114][115][116]. A causal link between shift/night work and weight gain/high body mass index is often reported, notably after 5 years, suggesting that shift/night work is a risk for type 2 diabetes [117]. Indeed, a retrospective study on 6413 male shift/night workers showed an increased risk of impaired glucose tolerance (even for workers with normal and stable bodyweight) compared to day workers [118]. Similarly, a recent meta-analysis reported an increased risk of 1.09 between shift/night work and type 2 diabetes [119]. Shift/night work is also often associated with chronic stress and a significant impact on cortisol (in humans) or corticosterone (in rodents) is well documented [120][121][122][123][124]. This is important because these hormones play a major role in the circadian resynchronization of the central and peripheral clocks in a chronic jet-lag context [122]. Given the importance of the circadian system in the regulation of female reproduction, and given the fetal exposure to the maternal daily rhythms in temperature, hormones and metabolic cues, female shift workers may display reproductive dysregulations. Indeed a few studies have reported increased risk of irregular menstrual cycles, endometriosis, miscarriage, low birth weight or pre-term delivery in women in shift/night work conditions [125][126][127]. Notably, an animal study showed that the functioning of fetal clocks depends on maternal hormones thus suggesting that maternal circadian disruption during pregnancy may lead to fetal SCN and peripheral clock desynchronisation [128]. 
Shift work is a very complex situation and therefore it is difficult to design animal model conditions that truly mimic human shift work which is often associated with potential confounding factors (diet, social stress, sleep disturbance, use of psychostimulants). Furthermore, most studies are carried out on nocturnal animals (rats, mice, hamster) while humans are diurnal. A part from melatonin, whose secretion is always at night, other hormones (cortisol/corticosterone, glucose, leptin, gonadotropins) and many biological functions (food intake, sleep/wake, cardiac functions, vigilance) have opposite rhythms between diurnal and nocturnal species. Moreover, for these studies male rodents are mainly used to avoid an effect of the female reproductive cycles in the measurement of the circadian disturbances. Yet, animal studies are essential for understanding the cellular and molecular mechanisms underlying circadian perturbations. A recent review listed four relevant models that use altered timing of either food intake, activity, sleep or light exposure, or a combination of several [129].

Few animal studies have investigated alteration in fertility or LH surge timing after a shift in the light/dark cycle or photoperiod. One study in female Syrian hamsters reported that after a 3h phase advance, the LH surge is not fully resynchronized to the new dark onset even after 3 days, but when they are submitted to a $3 \mathrm{~h}$ phase delay, the LH surge is synchronized more rapidly [130]. Further, photoperiod lengthening was associated with similar shifts in locomotor activity and the LH surge in female hamsters [62]. In mice, exposure to either phase advances or delays at the beginning and throughout pregnancy leads to a significant decrease in pregnancy success [131]. Finally, an in vitro study reported that the ovarian clock was not fully resynchronized 6 days after a $6 \mathrm{~h}$ phase advance in PER2::LUCIFERASE mice [132]. 
Taking advantage of a new blood LH micro-assay [133], we recently investigated the effect of a single $10 \mathrm{~h}$ phase advance on circulating $\mathrm{LH}$ and the estrous cycle length in C57BL/6 female mice (Bahougne et al. unpublished). After the 10h phase advance, the first two estrus cycles were longer and irregular and were restored at the third estrous cycle (with an average of 4.9 \pm 1.2 days for 9 mice). Figure 2 illustrates the shift of the pre-ovulatory LH surge in one representative mouse submitted to a $10 \mathrm{~h}$ phase advance: after the shift, the $\mathrm{LH}$ surge was delayed by 2-3 $\mathrm{h}$ at the first proestrus, displayed 2 peaks at the second proestrus, and was finally synchronized to the light/dark transition at the third proestrus. Altogether these preliminary data clearly indicate that a single phase shift can alter the timing of the LH surge and the length of the estrous cycles.

\section{Conclusions and Summary}

In female mammals the timing of ovulation depends on a large and transitory LH surge gated by high circulating estradiol produced by mature oocytes and a daily signal provided by the biological clock located in the suprachiasmatic nuclei. As shown in female rodents, in which the LH surge occurs at the end of the daytime resting period in proestrus, the suprachiasmatic nuclei appear to use two different pathways to forward daily signals to the reproductive system. Vasopressin neurons project to kisspeptin neurons to increase their activity precisely at the end of the day of proestrus, while vasoactive intestinal peptide decreases the activity of RFRP neurons at exactly the same time of the day. Given that kisspeptin stimulates and RFRP 
inhibits GnRH neurons and LH secretion, this coordinated activation of kisspeptin neurons and inactivation of RFRP neurons by the circadian clock allows a precise gating of the preovulatory LH surge at the end of the resting period. Epidemiological investigations together with animals studies now indicate that circadian disruption observed when the light/dark cycle is acutely (jet-lag) or chronically (shift work) shifted impairs the timing of the reproductive cycles.

\section{Acknowledgements}

TB is supported by the Fondation pour la Recherche Médicale for his $\mathrm{PhD}$ research stay (FDM20140630371). EA's PhD is supported by the European Erasmus mundus project Neurotime 


\section{References}

*[1] de Roux N, Genin E, Carel J-C, Matsuda F, Chaussain J-L, Milgrom E. Hypogonadotropic hypogonadism due to loss of function of the KiSS1-derived peptide receptor GPR54. Proc Natl Acad Sci U S A 2003;100:10972-6. doi:10.1073/pnas.1834399100.

[2] Seminara SB, Messager S, Chatzidaki EE, Thresher RR, Acierno JS, Shagoury JK, et al. The GPR54 gene as a regulator of puberty. N Engl J Med 2003;349:1614-27. doi:10.1056/NEJMoa035322.

[3] Pinilla L, Aguilar E, Dieguez C, Millar RP, Tena-Sempere M. Kisspeptins and reproduction: physiological roles and regulatory mechanisms. Physiol Rev 2012;92:1235-316. doi:10.1152/physrev.00037.2010.

[4] Clarkson J, Herbison AE. Postnatal development of kisspeptin neurons in mouse hypothalamus; sexual dimorphism and projections to gonadotropin-releasing hormone neurons. Endocrinology 2006;147:5817-25. doi:10.1210/en.2006-0787.

[5] Clarkson J, d'Anglemont de Tassigny X, Colledge WH, Caraty A, Herbison AE. Distribution of kisspeptin neurones in the adult female mouse brain. J Neuroendocrinol 2009;21:673-82. doi:10.1111/j.1365-2826.2009.01892.x.

[6] Hoong Yip S, Boehm U, Herbison AE, Campbell RE. Conditional viral tract-tracing delineates the projections of the distinct kisspeptin neuron populations to gonadotropinreleasing hormone (GnRH) neurons in the mouse. Endocrinology 2015:en20151131. doi:10.1210/en.2015-1131.

[7] Kauffman AS, Gottsch ML, Roa J, Byquist AC, Crown A, Clifton DK, et al. Sexual differentiation of Kiss1 gene expression in the brain of the rat. Endocrinology 2007;148:1774-83. doi:10.1210/en.2006-1540.

*[8] Smith JT, Popa SM, Clifton DK, Hoffman GE, Steiner RA. Kiss1 neurons in the 
forebrain as central processors for generating the preovulatory luteinizing hormone surge. J Neurosci 2006;26:6687-94. doi:10.1523/JNEUROSCI.1618-06.2006.

[9] Herbison AE, de Tassigny X d'Anglemont, Doran J, Colledge WH. Distribution and postnatal development of Gpr54 gene expression in mouse brain and gonadotropinreleasing hormone neurons. Endocrinology 2010;151:312-21. doi:10.1210/en.20090552.

[10] Simonneaux V, Ancel C, Poirel VJ, Gauer F. Kisspeptins and RFRP-3 Act in Concert to Synchronize Rodent Reproduction with Seasons. Front Neurosci 2013;7:22. doi:10.3389/fnins.2013.00022.

[11] Kotani M, Detheux M, Vandenbogaerde A, Communi D, Vanderwinden JM, Le Poul E, et al. The metastasis suppressor gene KiSS-1 encodes kisspeptins, the natural ligands of the orphan G protein-coupled receptor GPR54. J Biol Chem 2001;276:34631-6. doi:10.1074/jbc.M104847200.

[12] Gottsch ML, Cunningham MJ, Smith JT, Popa SM, Acohido B V, Crowley WF, et al. A role for kisspeptins in the regulation of gonadotropin secretion in the mouse. Endocrinology 2004;145:4073-7. doi:10.1210/en.2004-0431.

[13] Navarro VM, Castellano JM, Fernández-Fernández R, Tovar S, Roa J, Mayen A, et al. Characterization of the Potent Luteinizing Hormone-Releasing Activity of KiSS-1 Peptide, the Natural Ligand of GPR54. Endocrinology 2005;146:156-63. doi:10.1210/en.2004-0836.

[14] Dhillo WS, Chaudhri OB, Patterson M, Thompson EL, Murphy KG, Badman MK, et al. Kisspeptin-54 stimulates the hypothalamic-pituitary gonadal axis in human males. J Clin Endocrinol Metab 2005;90:6609-15. doi:10.1210/jc.2005-1468.

[15] Plant TM, Ramaswamy S, Dipietro MJ. Repetitive activation of hypothalamic G protein-coupled receptor 54 with intravenous pulses of kisspeptin in the juvenile 
monkey (Macaca mulatta) elicits a sustained train of gonadotropin-releasing hormone discharges. Endocrinology 2006;147:1007-13. doi:10.1210/en.2005-1261.

[16] Topaloglu AK, Tello JA, Kotan LD, Ozbek MN, Yilmaz MB, Erdogan S, et al. Inactivating KISS1 Mutation and Hypogonadotropic Hypogonadism. N Engl J Med 2012;366:629-35. doi:10.1056/NEJMoa1111184.

[17] d'Anglemont de Tassigny X, Fagg LA, Dixon JPC, Day K, Leitch HG, Hendrick AG, et al. Hypogonadotropic hypogonadism in mice lacking a functional Kiss1 gene. Proc Natl Acad Sci 2007;104:10714-9. doi:10.1073/pnas.0704114104.

[18] Brioude F, Bouligand J, Francou B, Fagart J, Roussel R, Viengchareun S, et al. Two Families with Normosmic Congenital Hypogonadotropic Hypogonadism and Biallelic Mutations in KISS1R (KISS1 Receptor): Clinical Evaluation and Molecular Characterization of a Novel Mutation. PLoS One 2013;8:e53896. doi:10.1371/journal.pone.0053896.

[19] Wahab F, Quinton R, Seminara SB. The kisspeptin signaling pathway and its role in human isolated GnRH deficiency. Mol Cell Endocrinol 2011;346:29-36. doi:10.1016/j.mce.2011.05.043.

[20] Donoso AO, Seltzer AM, Navarro CE, Cabrera RJ, López FJ, Negro-Vilar A. Regulation of luteinizing hormone-releasing hormone and luteinizing hormone secretion by hypothalamic amino acids. Braz J Med Biol Res 1994;27:921-32.

[21] Ottem EN, Godwin JG, Petersen SL. Glutamatergic signaling through the N-methyl-Daspartate receptor directly activates medial subpopulations of luteinizing hormonereleasing hormone (LHRH) neurons, but does not appear to mediate the effects of estradiol on LHRH gene expression. Endocrinology 2002;143:4837-45. doi:10.1210/en.2002-220707.

[22] Clasadonte J, Poulain P, Beauvillain J-C, Prevot V. Activation of neuronal nitric oxide 
release inhibits spontaneous firing in adult gonadotropin-releasing hormone neurons: a possible local synchronizing signal. Endocrinology 2008;149:587-96. doi:10.1210/en.2007-1260.

[23] Simonneaux V, Bur I, Ancel C, Ansel L, Klosen P. A kiss for daily and seasonal reproduction. Prog Brain Res 2012;199:423-37. doi:10.1016/B978-0-444-594273.00024-1.

[24] Rizwan MZ, Poling MC, Corr M, Cornes PA, Augustine RA, Quennell JH, et al. RFamide-related peptide-3 receptor gene expression in GnRH and kisspeptin neurons and GnRH-dependent mechanism of action. Endocrinology 2012;153:3770-9. doi:10.1210/en.2012-1133.

[25] Henningsen JB, Poirel V-J, Mikkelsen JD, Tsutsui K, Simonneaux V, Gauer F. Sex differences in the photoperiodic regulation of RF-Amide related peptide (RFRP) and its receptor GPR147 in the syrian hamster. J Comp Neurol 2016;524:1825-38. doi:10.1002/cne.23924.

[26] Quillet R, Ayachi S, Bihel F, Elhabazi K, Ilien B, Simonin F. RF-amide neuropeptides and their receptors in Mammals: Pharmacological properties, drug development and main physiological functions. Pharmacol Ther 2016;160:84-132. doi:10.1016/j.pharmthera.2016.02.005.

[27] Poling MC, Quennell JH, Anderson GM, Kauffman AS. Kisspeptin neurones do not directly signal to RFRP-3 neurones but RFRP-3 may directly modulate a subset of hypothalamic kisspeptin cells in mice. J Neuroendocrinol 2013;25:876-86. doi:10.1111/jne.12084.

[28] Ducret E, Anderson GM, Herbison AE. RFamide-related peptide-3, a mammalian gonadotropin-inhibitory hormone ortholog, regulates gonadotropin-releasing hormone neuron firing in the mouse. Endocrinology 2009;150:2799-804. doi:10.1210/en.2008- 
1623.

[29] Clarke IJ, Sari IP, Qi Y, Smith JT, Parkington HC, Ubuka T, et al. Potent Action of RFamide-Related Peptide-3 on Pituitary Gonadotropes Indicative of a Hypophysiotropic Role in the Negative Regulation of Gonadotropin Secretion. Endocrinology 2008;149:5811-21. doi:10.1210/en.2008-0575.

[30] Pineda R, Garcia-Galiano D, Sanchez-Garrido MA, Romero M, Ruiz-Pino F, Aguilar E, et al. Characterization of the inhibitory roles of RFRP3, the mammalian ortholog of $\mathrm{GnIH}$, in the control of gonadotropin secretion in the rat: in vivo and in vitro studies. Am J Physiol Endocrinol Metab 2010;299:E39-46. doi:10.1152/ajpendo.00108.2010.

[31] Ancel C, Inglis MA, Anderson GM. Central RFRP-3 Stimulates LH Secretion in Male Mice and Has Cycle Stage-Dependent Inhibitory Effects in Females. Endocrinology 2017;158:2873-83. doi:10.1210/en.2016-1902.

[32] Henningsen JB, Ancel C, Mikkelsen JD, Gauer F, Simonneaux V. Roles of RFRP-3 in the Daily and Seasonal Regulation of Reproductive Activity in Female Syrian Hamsters. Endocrinology 2017;158:652-63. doi:10.1210/en.2016-1689.

*[33] Christian CA, Mobley JL, Moenter SM. Diurnal and estradiol-dependent changes in gonadotropin-releasing hormone neuron firing activity. Proc Natl Acad Sci U S A 2005;102:15682-7. doi:10.1073/pnas.0504270102.

[34] White JO, Herschman MJ, Parmar G, Philipson KA, Elder MG, Habib NA, et al. Activated oestrogen receptor in human breast cancer: clinical and biochemical correlates. Br J Surg 1987;74:588-90.

[35] Radovick S, Levine JE, Wolfe A. Estrogenic regulation of the GnRH neuron. Front Endocrinol (Lausanne) 2012;3:52. doi:10.3389/fendo.2012.00052.

[36] Filardo EJ. Epidermal growth factor receptor (EGFR) transactivation by estrogen via the G-protein-coupled receptor, GPR30: a novel signaling pathway with potential 
significance for breast cancer. J Steroid Biochem Mol Biol 2002;80:231-8.

[37] Filardo EJ, Quinn JA, Bland KI, Frackelton AR. Estrogen-induced activation of Erk-1 and Erk-2 requires the G protein-coupled receptor homolog, GPR30, and occurs via trans-activation of the epidermal growth factor receptor through release of HB-EGF. Mol Endocrinol 2000;14:1649-60. doi:10.1210/mend.14.10.0532.

[38] Cheong RY, Porteous R, Chambon P, Abrahám I, Herbison AE. Effects of neuronspecific estrogen receptor (ER) $\alpha$ and ER $\beta$ deletion on the acute estrogen negative feedback mechanism in adult female mice. Endocrinology 2014;155:1418-27. doi:10.1210/en.2013-1943.

[39] Herbison AE, Theodosis DT. Localization of oestrogen receptors in preoptic neurons containing neurotensin but not tyrosine hydroxylase, cholecystokinin or luteinizing hormone-releasing hormone in the male and female rat. Neuroscience 1992;50:283-98.

[40] Smith JT, Cunningham MJ, Rissman EF, Clifton DK, Steiner RA. Regulation of Kiss1 gene expression in the brain of the female mouse. Endocrinology 2005;146:3686-92. doi:10.1210/en.2005-0488.

[41] Gottsch ML, Navarro VM, Zhao Z, Glidewell-Kenney C, Weiss J, Jameson JL, et al. Regulation of Kiss1 and dynorphin gene expression in the murine brain by classical and nonclassical estrogen receptor pathways. J Neurosci 2009;29:9390-5. doi:10.1523/JNEUROSCI.0763-09.2009.

[42] Ansel L, Bolborea M, Bentsen AH, Klosen P, Mikkelsen JD, Simonneaux V. Differential regulation of kiss 1 expression by melatonin and gonadal hormones in male and female Syrian hamsters. J Biol Rhythms 2010;25:81-91. doi:10.1177/0748730410361918.

[43] Adachi S, Yamada S, Takatsu Y, Matsui H, Kinoshita M, Takase K, et al. Involvement of anteroventral periventricular metastin/kisspeptin neurons in estrogen positive 
feedback action on luteinizing hormone release in female rats. J Reprod Dev 2007;53:367-78.

[44] Hoffman GE, Le WW, Franceschini I, Caraty A, Advis JP. Expression of fos and in vivo median eminence release of LHRH identifies an active role for preoptic area kisspeptin neurons in synchronized surges of LH and LHRH in the ewe. Endocrinology 2011;152:214-22. doi:10.1210/en.2010-0066.

[45] Tomikawa J, Homma T, Tajima S, Shibata T, Inamoto Y, Takase K, et al. Molecular characterization and estrogen regulation of hypothalamic KISS1 gene in the pig. Biol Reprod 2010;82:313-9. doi:10.1095/biolreprod.109.079863.

[46] Huijbregts L, de Roux N. KISS1 is down-regulated by 17beta-estradiol in MDA-MB231 cells through a nonclassical mechanism and loss of ribonucleic acid polymerase II binding at the proximal promoter. Endocrinology 2010;151:3764-72. doi:10.1210/en.2010-0260.

*[47] Mayer C, Acosta-Martinez M, Dubois SL, Wolfe A, Radovick S, Boehm U, et al. Timing and completion of puberty in female mice depend on estrogen receptor alphasignaling in kisspeptin neurons. Proc Natl Acad Sci U S A 2010;107:22693-8. doi:10.1073/pnas.1012406108.

[48] Molnár CS, Kalló I, Liposits Z, Hrabovszky E. Estradiol down-regulates RF-amiderelated peptide (RFRP) expression in the mouse hypothalamus. Endocrinology 2011;152:1684-90. doi:10.1210/en.2010-1418.

[49] Iwasa T, Matsuzaki T, Murakami M, Kinouchi R, Osugi T, Gereltsetseg G, et al. Developmental changes in the mammalian gonadotropin-inhibitory hormone $(\mathrm{GnIH})$ ortholog RFamide-related peptide (RFRP) and its cognate receptor GPR147 in the rat hypothalamus. Int J Dev Neurosci 2012;30:31-7. doi:10.1016/j.ijdevneu.2011.10.003.

[50] Poling MC, Kim J, Dhamija S, Kauffman AS. Development, sex steroid regulation, and 
phenotypic characterization of RFamide-related peptide (Rfrp) gene expression and RFamide receptors in the mouse hypothalamus. Endocrinology 2012;153:1827-40. doi:10.1210/en.2011-2049.

[51] Quennell JH, Rizwan MZ, Relf H-L, Anderson GM. Developmental and steroidogenic effects on the gene expression of RFamide related peptides and their receptor in the rat brain and pituitary gland. J Neuroendocrinol 2010;22:309-16. doi:10.1111/j.13652826.2010.01963.x.

[52] Clarke IJ, Cummins JT. The temporal relationship between gonadotropin releasing hormone $(\mathrm{GnRH})$ and luteinizing hormone $(\mathrm{LH})$ secretion in ovariectomized ewes. Endocrinology 1982;111:1737-9. doi:10.1210/endo-111-5-1737.

[53] Crowley WF, McArthur JW. Simulation of the normal menstrual cycle in Kallman's syndrome by pulsatile administration of luteinizing hormone-releasing hormone (LHRH). J Clin Endocrinol Metab 1980;51:173-5. doi:10.1210/jcem-51-1-173.

[54] Goodman RL, Hileman SM, Nestor CC, Porter KL, Connors JM, Hardy SL, et al. Kisspeptin, neurokinin B, and dynorphin act in the arcuate nucleus to control activity of the GnRH pulse generator in ewes. Endocrinology 2013;154:4259-69. doi:10.1210/en.2013-1331.

[55] Wakabayashi Y, Yamamura T, Sakamoto K, Mori Y, Okamura H. Electrophysiological and morphological evidence for synchronized GnRH pulse generator activity among Kisspeptin/neurokinin B/dynorphin A (KNDy) neurons in goats. J Reprod Dev 2013;59:40-8.

[56] Keen KL, Wegner FH, Bloom SR, Ghatei MA, Terasawa E. An increase in kisspeptin54 release occurs with the pubertal increase in luteinizing hormone-releasing hormone1 release in the stalk-median eminence of female rhesus monkeys in vivo. Endocrinology 2008;149:4151-7. doi:10.1210/en.2008-0231. 
[57] Plant TM. The role of KiSS-1 in the regulation of puberty in higher primates. Eur $\mathrm{J}$ Endocrinol 2006;155 Suppl:S11-6. doi:10.1530/eje.1.02232.

*[58] Choe HK, Kim H-D, Park SH, Lee H-W, Park J-Y, Seong JY, et al. Synchronous activation of gonadotropin-releasing hormone gene transcription and secretion by pulsatile kisspeptin stimulation. Proc Natl Acad Sci 2013;110:5677-82. doi:10.1073/pnas.1213594110.

[59] Hillier SG. Current concepts of the roles of follicle stimulating hormone and luteinizing hormone in folliculogenesis. Hum Reprod 1994;9:188-91.

[60] Legan SJ, Karsch FJ. A daily signal for the LH surge in the rat. Endocrinology 1975;96:57-62. doi:10.1210/endo-96-1-57.

[61] Bronson FH, Vom Saal FS. Control of the preovulatory release of luteinizing hormone by steroids in the mouse. Endocrinology 1979;104:1247-55. doi:10.1210/endo-104-51247.

[62] Moline ML, Albers HE, Todd RB, Moore-Ede MC. Light-dark entrainment of proestrous LH surges and circadian locomotor activity in female hamsters. Horm Behav 1981;15:451-8.

[63] McElhinny TL, Sisk CL, Holekamp KE, Smale L. A morning surge in plasma luteinizing hormone coincides with elevated Fos expression in gonadotropin-releasing hormone-immunoreactive neurons in the diurnal rodent, Arvicanthis niloticus. Biol Reprod 1999;61:1115-22.

[64] Kerdelhué B, Brown S, Lenoir V, Queenan JT, Jones GS, Scholler R, et al. Timing of initiation of the preovulatory luteinizing hormone surge and its relationship with the circadian cortisol rhythm in the human. Neuroendocrinology 2002;75:158-63. doi:48233.

[65] Hoffman RA, Reiter RJ. Pineal gland: influence on gonads of male hamsters. Science 
1965;148:1609-11.

[66] Bartness TJ, Powers JB, Hastings MH, Bittman EL, Goldman BD. The timed infusion paradigm for melatonin delivery: what has it taught us about the melatonin signal, its reception, and the photoperiodic control of seasonal responses? J Pineal Res $1993 ; 15: 161-90$.

[67] Hazlerigg DG, Simonneaux V. Seasonal reproduction in Mammals. Fourth edition. 2014.

[68] Revel FG, Saboureau M, Pévet P, Simonneaux V, Mikkelsen JD. RFamide-related peptide gene is a melatonin-driven photoperiodic gene. Endocrinology 2008;149:90212. doi:10.1210/en.2007-0848.

[69] Ancel C, Bentsen AH, Sébert M-E, Tena-Sempere M, Mikkelsen JD, Simonneaux V. Stimulatory effect of RFRP-3 on the gonadotrophic axis in the male Syrian hamster: the exception proves the rule. Endocrinology 2012;153:1352-63. doi:10.1210/en.20111622.

[70] Klosen P, Sébert M-E, Rasri K, Laran-Chich M-P, Simonneaux V. TSH restores a summer phenotype in photoinhibited mammals via the RF-amides RFRP3 and kisspeptin. FASEB J 2013;27:2677-86. doi:10.1096/fj.13-229559.

*[71] Lowrey PL, Takahashi JS. Genetics of circadian rhythms in Mammalian model organisms. Adv Genet 2011;74:175-230. doi:10.1016/B978-0-12-387690-4.00006-4.

[72] Albrecht U, Eichele G. The mammalian circadian clock. Curr Opin Genet Dev 2003;13:271-7.

[73] Berson DM, Dunn FA, Takao M. Phototransduction by retinal ganglion cells that set the circadian clock. Science 2002;295:1070-3. doi:10.1126/science.1067262.

[74] Provencio I, Rollag MD, Castrucci AM. Photoreceptive net in the mammalian retina. This mesh of cells may explain how some blind mice can still tell day from night. 
Nature 2002;415:493. doi:10.1038/415493a.

[75] Jin X, Shearman LP, Weaver DR, Zylka MJ, de Vries GJ, Reppert SM. A molecular mechanism regulating rhythmic output from the suprachiasmatic circadian clock. Cell 1999;96:57-68.

[76] Miller G. Neurobiology. Despite mutated gene, mouse circadian clock keeps on ticking. Science 2006;312:673. doi:10.1126/science.312.5774.673.

*[77] Menaker M, Murphy ZC, Sellix MT. Central control of peripheral circadian oscillators. Curr Opin Neurobiol 2013;23:741-6. doi:10.1016/j.conb.2013.03.003.

[78] Yoo S-H, Yamazaki S, Lowrey PL, Shimomura K, Ko CH, Buhr ED, et al. PERIOD2::LUCIFERASE real-time reporting of circadian dynamics reveals persistent circadian oscillations in mouse peripheral tissues. Proc Natl Acad Sci U S A 2004;101:5339-46. doi:10.1073/pnas.0308709101.

[79] Mohawk JA, Green CB, Takahashi JS. Central and peripheral circadian clocks in mammals. Annu Rev Neurosci 2012;35:445-62. doi:10.1146/annurev-neuro-060909153128.

*[80] Simonneaux V, Bahougne T. A Multi-Oscillatory Circadian System Times Female Reproduction. Front Endocrinol (Lausanne) 2015;6:157. doi:10.3389/fendo.2015.00157.

[81] Smarr BL, Gile JJ, de la Iglesia HO. Oestrogen-independent circadian clock gene expression in the anteroventral periventricular nucleus in female rats: possible role as an integrator for circadian and ovarian signals timing the luteinising hormone surge. $\mathrm{J}$ Neuroendocrinol 2013;25:1273-9. doi:10.1111/jne.12104.

[82] Russo KA, La JL, Stephens SBZ, Poling MC, Padgaonkar NA, Jennings KJ, et al. Circadian Control of the Female Reproductive Axis Through Gated Responsiveness of the RFRP-3 System to VIP Signaling. Endocrinology 2015:en20141762. 
doi:10.1210/en.2014-1762.

[83] Brown-Grant K, Raisman G. Abnormalities in reproductive function associated with the destruction of the suprachiasmatic nuclei in female rats. Proc R Soc Lond B Biol Sci 1977;198:279-96.

[84] Wiegand SJ, Terasawa E, Bridson WE, Goy RW. Effects of discrete lesions of preoptic and suprachiasmatic structures in the female rat. Alterations in the feedback regulation of gonadotropin secretion. Neuroendocrinology 1980;31:147-57.

[85] van der Horst GT, Muijtjens M, Kobayashi K, Takano R, Kanno S, Takao M, et al. Mammalian Cry1 and Cry2 are essential for maintenance of circadian rhythms. Nature 1999;398:627-30. doi:10.1038/19323.

*[86] Miller BH, Olson SL, Turek FW, Levine JE, Horton TH, Takahashi JS. Circadian clock mutation disrupts estrous cyclicity and maintenance of pregnancy. Curr Biol 2004;14:1367-73. doi:10.1016/j.cub.2004.07.055.

[87] Dolatshad H, Campbell EA, O’Hara L, Maywood ES, Hastings MH, Johnson MH. Developmental and reproductive performance in circadian mutant mice. Hum Reprod 2006;21:68-79. doi:10.1093/humrep/dei313.

[88] Ratajczak CK, Boehle KL, Muglia LJ. Impaired steroidogenesis and implantation failure in Bmal1-/- mice. Endocrinology 2009;150:1879-85. doi:10.1210/en.20081021.

[89] Chu A, Zhu L, Blum ID, Mai O, Leliavski A, Fahrenkrug J, et al. Global but not gonadotrope-specific disruption of Bmal1 abolishes the luteinizing hormone surge without affecting ovulation. Endocrinology 2013;154:2924-35. doi:10.1210/en.20131080.

[90] Kovanen L, Saarikoski ST, Aromaa A, Lönnqvist J, Partonen T. ARNTL (BMAL1) and NPAS2 gene variants contribute to fertility and seasonality. PLoS One 
2010;5:e10007. doi:10.1371/journal.pone.0010007.

[91] Harney JP, Scarbrough K, Rosewell KL, Wise PM. In vivo antisense antagonism of vasoactive intestinal peptide in the suprachiasmatic nuclei causes aging-like changes in the estradiol-induced luteinizing hormone and prolactin surges. Endocrinology 1996;137:3696-701. doi:10.1210/endo.137.9.8756535.

[92] Funabashi T, Aiba S, Sano A, Shinohara K, Kimura F. Intracerebroventricular injection of arginine-vasopressin V1 receptor antagonist attenuates the surge of luteinizing hormone and prolactin secretion in proestrous rats. Neurosci Lett 1999;260:37-40.

[93] Palm IF, Van Der Beek EM, Wiegant VM, Buijs RM, Kalsbeek A. Vasopressin induces a luteinizing hormone surge in ovariectomized, estradiol-treated rats with lesions of the suprachiasmatic nucleus. Neuroscience 1999;93:659-66.

[94] van der Beek EM, Swarts HJ, Wiegant VM. Central administration of antiserum to vasoactive intestinal peptide delays and reduces luteinizing hormone and prolactin surges in ovariectomized, estrogen-treated rats. Neuroendocrinology 1999;69:227-37. doi:54423.

[95] Sun Y, Shu J, Kyei K, Neal-Perry GS. Intracerebroventricular infusion of vasoactive intestinal Peptide rescues the luteinizing hormone surge in middle-aged female rats. Front Endocrinol (Lausanne) 2012;3:24. doi:10.3389/fendo.2012.00024.

[96] Williams WP, Jarjisian SG, Mikkelsen JD, Kriegsfeld LJ. Circadian Control of Kisspeptin and a Gated GnRH Response Mediate the Preovulatory Luteinizing Hormone Surge. Endocrinology 2011;152:595-606. doi:10.1210/en.2010-0943.

[97] Vida B, Deli L, Hrabovszky E, Kalamatianos T, Caraty A, Coen CW, et al. Evidence for suprachiasmatic vasopressin neurones innervating kisspeptin neurones in the rostral periventricular area of the mouse brain: regulation by oestrogen. J Neuroendocrinol 2010;22:1032-9. doi:10.1111/j.1365-2826.2010.02045.x. 
[98] Kalsbeek A, Buijs RM, Engelmann M, Wotjak CT, Landgraf R. In vivo measurement of a diurnal variation in vasopressin release in the rat suprachiasmatic nucleus. Brain Res 1995;682:75-82.

*[99] Piet R, Fraissenon A, Boehm U, Herbison AE. Estrogen permits vasopressin signaling in preoptic kisspeptin neurons in the female mouse. J Neurosci 2015;35:6881-92. doi:10.1523/JNEUROSCI.4587-14.2015.

[100] Horvath TL, Cela V, van der Beek EM. Gender-specific apposition between vasoactive intestinal peptide-containing axons and gonadotrophin-releasing hormone-producing neurons in the rat. Brain Res 1998;795:277-81.

[101] Robertson JL, Clifton DK, de la Iglesia HO, Steiner RA, Kauffman AS. Circadian regulation of Kiss1 neurons: implications for timing the preovulatory gonadotropinreleasing hormone/luteinizing hormone surge. Endocrinology 2009;150:3664-71. doi:10.1210/en.2009-0247.

*[102]Chassard D, Bur I, Poirel V-J, Mendoza J, Simonneaux V. Evidence for a putative circadian Kiss-Clock in the hypothalamic AVPV in female mice. Endocrinology 2015:en20141769. doi:10.1210/en.2014-1769.

[103] Ubuka T, Inoue K, Fukuda Y, Mizuno T, Ukena K, Kriegsfeld LJ, et al. Identification, expression, and physiological functions of Siberian hamster gonadotropin-inhibitory hormone. Endocrinology 2012;153:373-85. doi:10.1210/en.2011-1110.

[104] Jørgensen SR, Andersen MD, Overgaard A, Mikkelsen JD. Changes in RFamiderelated peptide-1 (RFRP-1)-immunoreactivity during postnatal development and the estrous cycle. Endocrinology 2014;155:4402-10. doi:10.1210/en.2014-1274.

[105] Clarke IJ, Smith JT, Henry BA, Oldfield BJ, Stefanidis A, Millar RP, et al. Gonadotropin-Inhibitory Hormone Is a Hypothalamic Peptide That Provides a Molecular Switch between Reproduction and Feeding. Neuroendocrinology 
2012;95:305-16. doi:10.1159/000332822.

[106] Pati, A., Chandrawanshi, A., \& Reinberg A. Shift work: consequences and management. Curr Sci 2001:81, 32-52.

[107] Boivin DB, Tremblay GM, James FO. Working on atypical schedules. Sleep Med 2007;8:578-89. doi:10.1016/j.sleep.2007.03.015.

[108] Chen J-D, Lin Y-C, Hsiao S-T. Obesity and high blood pressure of 12-hour night shift female clean-room workers. Chronobiol Int 2010;27:334-44. doi:10.3109/07420520903502242.

[109] Matheson A, O’Brien L, Reid J-A. The impact of shiftwork on health: a literature review. J Clin Nurs 2014;23:3309-20. doi:10.1111/jocn.12524.

[110] Bøggild H, Knutsson A. Shift work, risk factors and cardiovascular disease. Scand J Work Environ Health 1999;25:85-99.

[111] Frost P, Kolstad HA, Bonde JP. Shift work and the risk of ischemic heart disease - a systematic review of the epidemiologic evidence. Scand J Work Environ Health 2009;35:163-79.

[112] Vyas M V, Garg AX, Iansavichus A V, Costella J, Donner A, Laugsand LE, et al. Shift work and vascular events: systematic review and meta-analysis. BMJ 2012;345:e4800. doi:10.1136/bmj.e4800.

[113] Carreón T, Hein MJ, Hanley KW, Viet SM, Ruder AM. Coronary artery disease and cancer mortality in a cohort of workers exposed to vinyl chloride, carbon disulfide, rotating shift work, and o-toluidine at a chemical manufacturing plant. Am J Ind Med 2014;57:398-411. doi:10.1002/ajim.22299.

[114] Hermansson J, Gillander Gådin K, Karlsson B, Reuterwall C, Hallqvist J, Knutsson A. Case fatality of myocardial infarction among shift workers. Int Arch Occup Environ Health 2015;88:599-605. doi:10.1007/s00420-014-0984-z. 
[115] Gu F, Han J, Laden F, Pan A, Caporaso NE, Stampfer MJ, et al. Total and CauseSpecific Mortality of U.S. Nurses Working Rotating Night Shifts. Am J Prev Med 2015;48:241-52. doi:10.1016/j.amepre.2014.10.018.

[116] Park S, Nam J, Lee J-K, Oh S-S, Kang H-T, Koh S-B. Association between night work and cardiovascular diseases: analysis of the 3rd Korean working conditions survey. Ann Occup Environ Med 2015;27:15. doi:10.1186/s40557-015-0064-1.

[117] Pan A, Schernhammer ES, Sun Q, Hu FB. Rotating night shift work and risk of type 2 diabetes: two prospective cohort studies in women. PLoS Med 2011;8:e1001141. doi:10.1371/journal.pmed.1001141.

[118] Oyama I, Kubo T, Fujino Y, Kadowaki K, Kunimoto M, Shirane K, et al. Retrospective cohort study of the risk of impaired glucose tolerance among shift workers. Scand J Work Environ Health 2012;38:337-42. doi:10.5271/sjweh.3297.

[119] Gan Y, Yang C, Tong X, Sun H, Cong Y, Yin X, et al. Shift work and diabetes mellitus: a meta-analysis of observational studies. Occup Environ Med 2015;72:72-8. doi:10.1136/oemed-2014-102150.

[120] Goichot B, Weibel L, Chapotot F, Gronfier C, Piquard F, Brandenberger G. Effect of the shift of the sleep-wake cycle on three robust endocrine markers of the circadian clock. Am J Physiol 1998;275:E243-8.

[121] Weibel L, Brandenberger G. The start of the quiescent period of cortisol remains phase locked to the melatonin onset despite circadian phase alterations in humans working the night schedule. Neurosci Lett 2002;318:89-92.

[122] Oster H. Adrenal glucocorticoids have a key role in circadian resynchronization in a mouse model of jet lag. - PubMed - NCBI. J Clin Invest 2010:2600-9.

[123] Gumenyuk V, Howard R, Roth T, Korzyukov O, Drake CL. Sleep loss, circadian mismatch, and abnormalities in reorienting of attention in night workers with shift 
work disorder. Sleep 2014;37:545-56. doi:10.5665/sleep.3494.

[124] Ulhôa MA, Marqueze EC, Burgos LGA, Moreno CRC. Shift work and endocrine disorders. Int J Endocrinol 2015;2015:826249. doi:10.1155/2015/826249.

[125] Lawson CC, Whelan EA, Lividoti Hibert EN, Spiegelman D, Schernhammer ES, RichEdwards JW. Rotating shift work and menstrual cycle characteristics. Epidemiology 2011;22:305-12. doi:10.1097/EDE.0b013e3182130016.

[126] Rocheleau CM, Lawson CC, Whelan EA, Rich-Edwards JW. Shift work and adverse pregnancy outcomes: comments on a recent meta-analysis. BJOG 2012;119:378; author reply 379-80. doi:10.1111/j.1471-0528.2011.03211.x.

[127] Gamble KL, Resuehr D, Johnson CH. Shift work and circadian dysregulation of reproduction. Front Endocrinol (Lausanne) 2013;4:92. doi:10.3389/fendo.2013.00092.

[128] Torres-Farfan C, Mendez N, Abarzua-Catalan L, Vilches N, Valenzuela GJ, SeronFerre M. A circadian clock entrained by melatonin is ticking in the rat fetal adrenal. Endocrinology 2011;152:1891-900. doi:10.1210/en.2010-1260.

[129] Opperhuizen A-L, van Kerkhof LWM, Proper KI, Rodenburg W, Kalsbeek A. Rodent models to study the metabolic effects of shiftwork in humans. Front Pharmacol 2015;6:50. doi:10.3389/fphar.2015.00050.

[130] Moline ML, Albers HE. Response of circadian locomotor activity and the proestrous luteinizing hormone surge to phase shifts of the light-dark cycle in the hamster. Physiol Behav 1988;43:435-40.

[131] Summa KC, Vitaterna MH, Turek FW. Environmental perturbation of the circadian clock disrupts pregnancy in the mouse. PLoS One 2012;7:e37668. doi:10.1371/journal.pone.0037668.

[132] Yamazaki S, Numano R, Abe M, Hida A, Takahashi R, Ueda M, et al. Resetting central and peripheral circadian oscillators in transgenic rats. Science 2000;288:682-5. 
[133] Steyn FJ, Wan Y, Clarkson J, Veldhuis JD, Herbison AE, Chen C. Development of a methodology for and assessment of pulsatile luteinizing hormone secretion in juvenile and adult male mice. Endocrinology 2013;154:4939-45. doi:10.1210/en.2013-1502. 


\section{Figure 1}

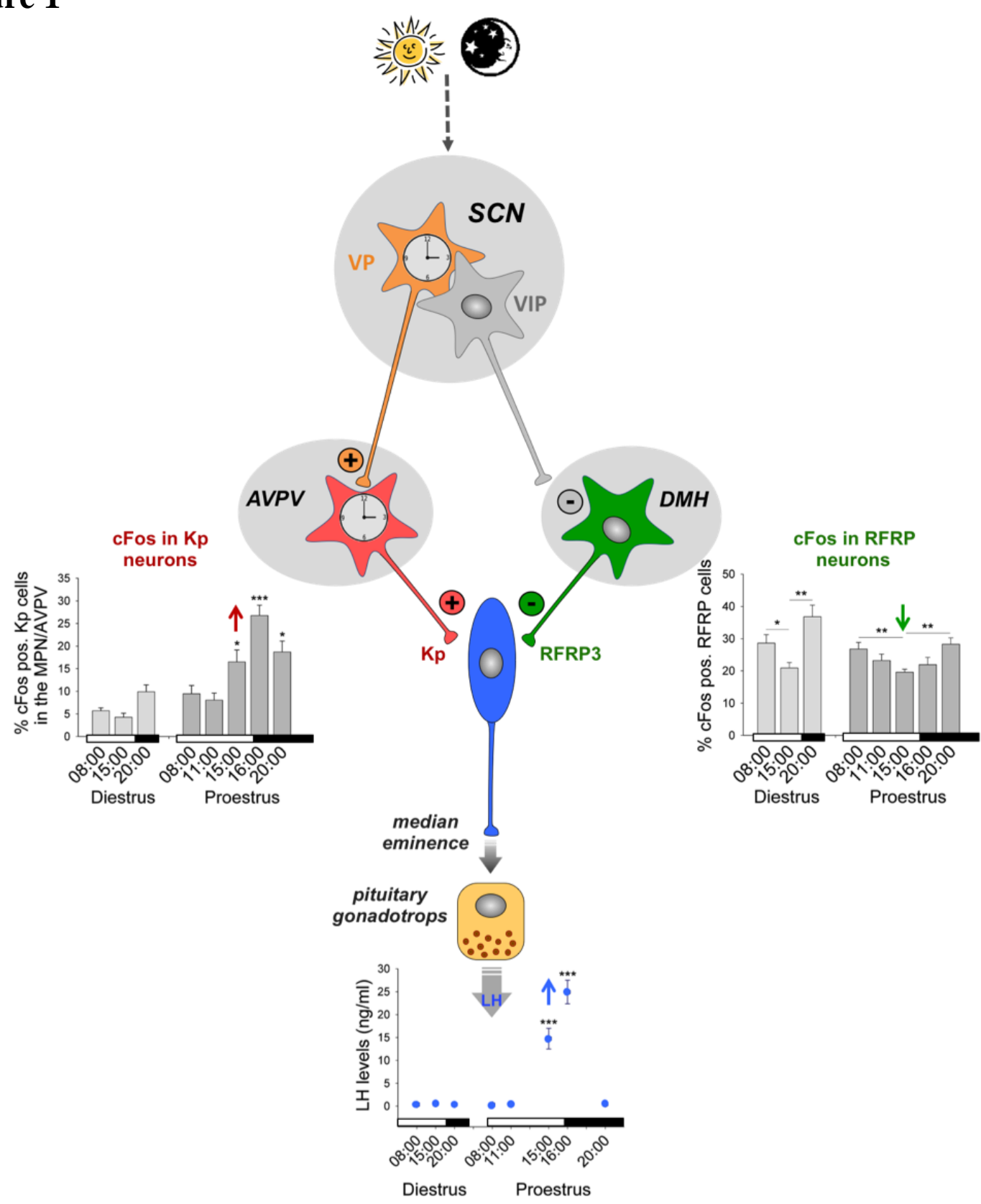

Model of a neuronal network controlling the gating of the LH surge at the day/night transition of the estrous stage in female mice. Neuronal activity of the circadian biological clock located in the suprachiamsatic nuclei $(\mathrm{SCN})$ is synchronized by the daily change in light and dark. SCN vasopressin (VP) neurons project to kisspeptin (Kp) neurons located at the anteroventral periventricular nuclei (AVPV) and VP is released at the end of the light phase to activate Kp neurons (c-Fos expression) only at the proestrus stage (due to the permissive effect of high circulating estradiol at this stage). SCN vasoactive intestinal peptide (VIP) project to (Arg)(Phe)related peptide (RFRP) neurons located at the dorsomedial hypothalamus (DMH) and VIP inhibits, possibly via an indirect pathway, RFRP neuronal activity (cFOS expression) at the end of afternoon of both proestrus and diestrus stages. Kp exerts a strong stimulation on the GnRH-induced LH release whereas RFRP-3 reduces the elevated LH secretion. Thus, the SCN appears to induce a coordinated increase of the stimulatory Kp (via VP) and decrease of the inhibitory RFRP-3 (via VIP) in order to allow a full activation of LH secretion at the light/dark transition on the day of proestrus. Adapted from Henningsen et al., 2017. 


\section{Figure 2}

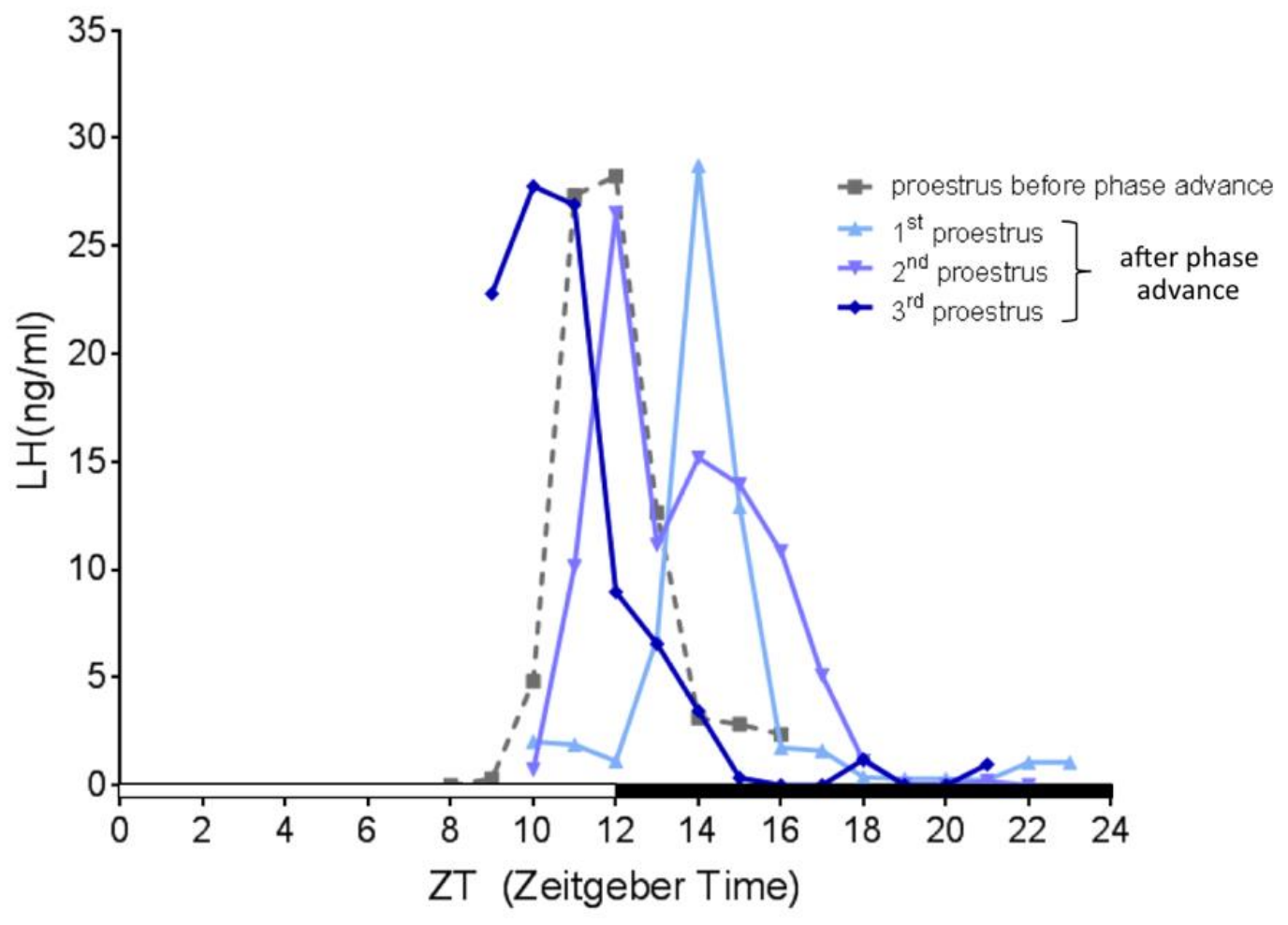

Timing of the LH surge in one mouse submitted to a 10h phase advance. The adult female mouse was adapted to a 12h light/12dark cycle with light on at ZT (zeitgeber) 0 and light off at ZT12. The estrous cycle was followed by vaginal smears and LH levels were measured by radioimmunassay in $4 \mu \mathrm{l}$ tail blood sampled every hour. Before the phase advance, the LH surge (grey dotted line) occurs at the very end of the light phase (ZT11-ZT12). After the $10 \mathrm{~h}$ phase advance, estrous cycles and LH secretion were followed. The LH surge of the first proestrus stage after the shift occurs 2 hours after lights off (ZT14); the surge displays two peaks (at ZT14 and ZT12) at the second proestrus stage; and at the third proestrus after the shift the LH surge is finally gated at the new day/night transition (ZT10-ZT11). Preliminary data from Bahougne and Simonneaux (unpublished) 